\title{
Chapter 12 \\ Lone Mothers in Belgium: Labor Force Attachment and Risk Factors
}

\author{
Emanuela Struffolino and Dimitri Mortelmans
}

\section{Introduction}

The risk of welfare dependency for lone mothers is one of the major concerns in the socio-political debate connected to the increasing number of lone parent families in most of the European countries. In fact, lone mothers are more likely than mothers in couples to be poor, unemployed, and welfare recipients. Even though paid work is considered one of the preferential ways to avoid poverty and welfare dependency, individual and family characteristics define a variety of labour supply strategies. It follows that the typical work-first and welfare-to-work measures aiming to support employment for lone mothers that have been implemented in many countries might actually target a group that is highly internally differentiated, thus resulting in extremely mixed outcomes (Haux 2013; Lewis 2009).

Lone parents are mainly women, and as such might be confronted - when the transition to lone parenthood occurs - with additional burdens due, for example, to difficulties in re-entering the labour market after inactivity or in existing social assistance because of the increase in care responsibilities driven by being primary carer and breadwinner. It follows that experiencing lone motherhood might result in strategies for balancing work and life by mixing welfare and labour supply that differ according to previous and current resources as well as household characteristics. Furthermore, changes in the demographic characteristics of lone parents (Berrington 2014; Kiernan 2004) are likely to interact with traditional factors of inequality once one looks at specific life domains, such as integration within the national/regional labour market or through the welfare system itself.

\author{
E. Struffolino $(\bowtie)$ \\ WZB Berlin Social Science Center and Humboldt University, Berlin, Germany \\ e-mail: emanuela.struffolino@wzb.eu \\ D. Mortelmans \\ CLLS, Faculty of Social Sciences, University of Antwerp, Antwerp, Belgium
}


The relationship between lone parenthood and labour market participation has been studied in terms of (i) the differential probability of being employed, comparing lone mothers and mothers in couples (Western et al. 2008); (ii) single transitions (and their timing) in and out of the labour market after becoming a lone mother (Stewart 2009); and (iii) the responsiveness to incentives (if any) for lone mothers to move off welfare and into work (Athreya et al. 2010; Dowler 1998; D'Souza et al. 2008). However, the strategies adopted to balance family and work domains after the transition to lone parenthood cannot be captured by means of cross-sectional analysis looking at behaviours at a single point in time over the life course.

Women who experience lone motherhood for a certain period of time over their life course have to face the resulting increase in economic and care needs in the household. Despite the tremendous changes that have occurred in terms of women's employment opportunities and configuration of gender roles within the family, women are more exposed than men to poverty risk due to the decrease in household income after separation or divorce (Andreß et al. 2006; De Regt et al. 2013; Jarvis and Jenkins 1999; Poortman 2000; Smock 1994; Smock et al. 1999). The strategies individuals can adopt to respond to the consequences of changes in the family life domain, such as increased economic and care burdens, depend on the characteristics of both the welfare system and the labour market structure.

By embracing a life course perspective and thus considering the dynamics of family trajectories, we stress the importance of looking at differentiation within the group of women who experience at least one episode of lone motherhood right after their break-up. In fact, it has been argued that family disruption is one of those new social risks that might shape differently the exposure to vulnerability of different groups when interacting with more traditional social risks, such as a weak labour market attachment or welfare dependency (Bonoli 2005; Vandecasteele 2010). For this reason, looking directly at the variety of experiences of this specific group of women who have to deal with work-family reconciliation to a much greater extent than mothers living in couples might shed light on the effect of household characteristics and the timing of the transition to lone motherhood on labour market participation and/or welfare dependency (Drobnič 2000).

Building on the few previous studies on the variability among individuals' employment trajectories following the transition to lone parenthood (Stewart 2009; Zagel 2013), the aim of the present chapter is to describe the nature of such variability in the Flemish case. In Belgium, lone parent families represent almost one fourth of households with children (Wagener et al. 2014). Regional differences exist, but the proportion of lone parent families exceeds at least $20 \%$ everywhere. In Flanders in particular, the poverty risk for this type of family is significantly higher compared to couple-with-children households and to the general population itself, even though welfare provisions are available to a relatively great extent for different types of recipients. Furthermore, on the one hand, the Flemish region accounts for the majority of women who exploit the career break system meant to encourage labour force attachment and return after parental leave, but on the other hand, it scores worse than the other Belgian regions where female labour market participation is concerned. 
In this context, the high incentives to take employment and the low impact of childcare costs on income gain are also combined with relatively generous unemployment benefits for the long-term unemployed (Immervol and Scarpetta 2012). These factors might lead to opposite outcomes when the labour supply strategies of lone mothers are considered. In fact, two opposite mechanisms can affect labour market participation: on the one hand, favourable childcare arrangement and further incentives for working can facilitate it, and on the other hand, welfare generosity might be discouraging. Nevertheless, from a medium and long-term perspective, a weak labour market attachment can undermine future opportunities due to skills depreciation processes. Since the result of this trade-off between the needs for care and for income within the household that emerges during lone parenthood is shaped by both individual and household characteristics, inequalities within the population of lone mothers might reinforce existing disadvantages in terms of differential in the risk of social exclusion driven by family structure and labour market arrangement. Thus, we firstly consider whether the age at the transition to lone motherhood acts as a stratification variable when looking at labour market opportunities, which are frequently path and seniority dependent. Furthermore, we explore the relationship between employment trajectories and partnership status before lone parenthood, as well as the number and age of children in the household as a proxy for the potential effect of care responsibilities on labour supply. Register data from the Crossroads bank of Social Security (CBSS Datawarehouse) allow us to track labour market participation pathways of Flemish women who experienced the transition to lone parenthood after divorcing in 2004.

\section{Lone Parenthood Between Welfare and Labour Market Participation}

Partnership dissolution can be seen as a risk not contemplated as part of standard life-course expectations as conceived in the industrial society (Vandecasteele 2011). The increase in the share of individuals who experience lone parenthood is thus a by-product of the second demographic transition, and increasing exposure to the economic risks of this type of family is a consequence of the transition to a postindustrial society, which is associated with changes in women's labour market participation, growing unemployment and in-work poverty. Against this scenario, the role of coupledom in providing life-long economic security is revealing its inadequacy. The transition to lone parenthood is accompanied by changing needs in terms of care and income that can trigger employment choices strongly shaped by resources made available by the welfare state. It follows that life chances and exposure to what are considered new social risks connected to life-course events in the family domain are strongly shaped by welfare state provisions and labour market structure (Bonoli 2005; DiPrete and McManus 2000; Taylor-Gooby 2004). 
When considering the relationship between family structure and employment choices, one has to acknowledge that different institutional settings provide lone mothers with different scenarios they might access, since welfare state regimes can indeed either promote a traditional male breadwinner model of work and care or rather encourage dual-earner families. In both cases, however, if welfare support is scarce, the risk of poverty increases as a consequence of the sudden lack of money from the father and necessitates a re-arrangement of labour supply for the mother, who usually holds custody of the children and thus the increased need for care within the household (Christopher et al. 2000; Esping-Andersen 1999; Garfinkel et al. 1994).

Cross-national studies show that lone mothers work less than mothers in couples, and that lone mothers' full-time engagement in the labor market is higher in countries in which work policies are more flexible (Plantenga et al. 2010; Ruggeri and Bird 2014). In other words, even if in many countries the activity rate of lone mothers has been increasing during the last decades (Cohen 2002), not having a partner exposes women to higher unemployment risk and persistent poverty (Eamon and $\mathrm{Wu}$ 2011). The process of feminization of poverty has been acknowledged since the 1990s for the United States (Daly 2000), and this is likely to shape the new borders of poverty risk in many European countries in correspondence to the increasing share of women who experience lone parenthood. In fact, women suffer more than men from the decrease in household income after divorce (De Regt et al. 2013; Jenkins 2009; Rake 2000), with recovery from this drop in economic resources lasting between 4 and 6 years depending on the context (De Vaus et al. 2014; Mckay 2002; Mortelmans 2017). Furthermore, experiencing exposure to poverty risk, as well as to stress factors caused by the trade-off between care and employment during periods spent as lone parents, has been found to become chronic even after repartnering (Friedland and Price 2003).

When looking at the interaction between welfare, employment, and lone parenthood in contexts in which self-sufficiency and economic independence are rather strongly promoted by activation policies for benefit recipients (Daly 2011), the main issue lone mothers have to face is how to combine work with parenting (Haux 2013). In the literature, the concept of "barriers to employment" formalizes the pool of factors interacting in such reconciliation process (Moffitt et al. 2002). Both individual and structural characteristics might represent barriers: in fact, personal physical/psychological health, individual skills, and work experience can act both independently from and in interaction with additional obstacles such as family size, availability of affordable childcare (Daycare Trust 2011; Millar and Ridge 2008), employer prejudices and, in general, labor market opportunities (Gingerbread $2012)^{1}$ in threatening the possibility of increasing one's labour supply.

\footnotetext{
${ }^{1}$ Several analyses cannot account for individual preferences to stay at home to care for children vs. working (Tomaszewski et al. 2010; Duncan and Edwards 1997): not controlling for this unobserved heterogeneity for the selection into unemployment might lead to misinterpret the (spurious) relationship between actual employment status and lone parenthood. Nonetheless, it is worth firstly noticing that evidence on impact of individual attitudes and institutions is mixed: on the one
} 
Consistently with the aim of this chapter, we focus here only on some of these factors. The first structural characteristic is the welfare system. On the one hand, policy measures for supporting lone mothers can sustain employment, such as in the cases of Germany and the US, where public childcare is made available for lone mothers, who work at higher rates than mothers in couples (Zagel 2013). On the other hand, policies can promote a social assistance payment system, as in the United Kingdom where in general lone mothers work less than mothers living in couples (Millar and Rowlingson 2001). Income-related arrangements (such as welfare subsidies for poor families, which are usually lone parent families) are found to be more effective in alleviating the economic drawbacks of divorce than employmentrelated arrangements (Uunk 2004) and to promote employment especially among low-income lone mothers (Ahn 2012). The availability of reconciliation policies itself might not be sufficient to eliminate the barriers to work. For example, long childcare leaves without benefits are suitable for parents in a family with one breadwinner, while widespread public or subsidized childcare support reconciliation for more family types and women's labour market participation in general (Boeckmann et al. 2014; Korpi 2000; Korpi et al. 2013; Van der Lippe and Van Dijk 2002). In fact, high costs for childcare are discouraging, especially for low-income families and lone parents in particular (Connelly and Kimmel 2003). When a family cannot rely on informal help from relatives, then the market supply of working mothers might decrease to a great extent (Herbst and Tekin 2011).

However, assuming that lone mothers react to the welfare state configuration by following a rational economic approach, as is more or less implicitly expected by many welfare-to-work measures, would be misleading. In fact, not just because plenty of opportunities for working full time are available, lone mothers might decide to fully delegate childcare (Duncan and Edwards 1997). In other words, gender pressure might act independently from economic pressure. Furthermore, the care-employment trade-off with which women have to cope is strictly connected to both the different social expectations towards motherhood and the type of labour demand lone mothers can actually access. In fact, in several countries in which the male breadwinner model prevails, mothers in couples are not expected to be strongly engaged in the labour market due to their care responsibilities within the household. In those same national contexts, lone mothers are instead asked to increase their labour supply to contrast welfare dependency through work. Evidence shows that lone parent families rely more and for longer periods on welfare support than other types of household do (Voges et al. 1996). However, as the increase in in-work poverty shows clearly (Andreß and Lohmann 2008; Cooke and Lawton 2008), working itself does not protect against poverty, being a necessary but not sufficient condition for self-sufficiency. In the presence of low wages and unfavourable working conditions (temporary contracts, shift works, no health insurance, no vacation benefits, etc.),

hand, structural barriers rather than preferences are found to be crucial, and especially those connected to childcare and labor market opportunities (Whitworth 2013); on the other hand, there is some evidence that shows that those who experience lone parenthood at certain point over the life course had already low rates of employment (Mckay 2002). 
lone mothers might not be able to move off welfare through work, and thus they have to combine welfare and work (Cancian and Meyer 2000; Eamon and Wu 2011; Millar and Ridge 2008; Wu et al. 2008).

Structural barriers in particular interact with individual and household characteristics. Where the first are concerned, previous research shows that when motherhood occurs early in the life course, individuals who did not complete education could be funnelled in a spiral of cumulative disadvantages in the labour market and wage-wise as well as across life domains (Chevalier and Viitanen 2003; Looze 2014). Furthermore, it can be assumed that when lone parenthood has occurred at a young age, mothers might not have enough qualifications and labour-market experience to endorse and thus have less bargaining power and are more exposed to underemployment. In contrast, those who become lone mothers at an older age have cumulated experience, and this seniority benefit (and related benefits) might increase the opportunity to obtain better compromises to reconciliate paid work and family care (Ondrich et al. 2003). Similarly, older lone mothers are found to be less likely to suffer from economic hardship (Bauman 2002)2. Results from cross-sectional data of European countries as a whole show that young lone mothers work less than young mothers in couples, and that this gap is smaller across groups of older women (Ruggeri and Bird 2014).

The relationship status before lone parenthood - namely whether the couple was married or cohabited - cannot be strictly conceived as a "barrier" to employment, but there is evidence that some kind of selection results in cohabiters showing a more equal division of paid work compared to married couples, and married women being on average more economically dependent on their partners (Snoeckx et al. 2008). Thus, divorced women suffer from a greater disadvantage for being divorced than cohabiting women who were formerly more independent, thanks to a stronger presence in the labour market. It follows that heterogeneity exists in the economic effects of union dissolution according to previous relationship status, but it is mainly driven by previous employment status. In this understanding, having been married or having cohabited before the transition to lone parenthood might represent an additional disadvantage connected - again - to experience in the labour market and to age at lone parenthood.

When considering household characteristics, the number and age of children have been found to be crucial in allowing lone parents to give up employment and care for their children as their main occupation (Kasparova et al. 2003; Millar and Ridge 2008) . For example, in Germany, mothers in couples are less likely to work

\footnotetext{
${ }^{2}$ Unfortunately, as discussed below, here we are using register data and information on education is not available. However, we know from the human capital theory (Becker 1975; Mincer 1974) that different investment on education defines different opportunities in the labor market and in wage growth pace. In particular, leaving labor market for some years is found to matter more for highly educated than for low-skilled women (Stewart 2009). It follows that since highly skilled women invested more in education and they expect higher returns, they will be less likely to leave the labor forces (and relying completely on welfare) and more likely to have external resources to mobilize for re-conciliating work and care independently from formal childcare availability and its cost.
} 
than lone mothers, but when they have a larger family they re-enter the workforce (and often full time) to the same extent as lone mothers do. In the US, heading a large family interferes with work off welfare (Harris 1993), but the age of the youngest child in the household is even more important in defining the labour market supply of lone mothers (Drobnič 2000). Similarly to the US, evidence from the UK and Australia shows that welfare measures promoting employment of lone mothers are more effective as the children grow up, and lone mothers with children older than pre-school age have much higher employment rates (Doiron 2004; Ermisch and Wright 1995).

This brief review aimed to account for the available evidence on the association between lone motherhood and labour market participation. However, most of the research either relies on cross-sectional data (which are not suitable for looking at evolution of processes over time) or uses longitudinal data for estimating the timing of occurrence of certain events, such as re-entering the labour market or getting a certain type of job. Even though it can be argued that selection into lone parenthood exists, an increasing heterogeneity is found when observing different cohorts of births and the distribution of lone parents over variables such as education and age (OECD 2014). It follows that differences in the mechanisms behind labour market participation strategies could not emerge when looking at cross-sectional data, while what really differs is the trajectory/pattern according to different stratification variables. Most of the research reviewed above relies on cross-sectional data. However, when we consider lone parenthood, the time from the transition to the new family arrangement is crucial to understand how strategies to combine care and work evolve: cross-sectional analyses are blind to such changes because they cannot follow individuals over time. The little existing evidence from longitudinal data shows that activity rates among mothers (including welfare recipients) are higher than the results of cross-sectional analyses (Harris 1993), and studies that exploit longitudinal data to look directly at trajectories of lone mothers show great variability according to the duration of lone parenthood (Zagel 2013; Stewart 2009). These results support the idea that bringing about within-group comparisons is useful to detect grey areas where old social risks and new ones connect to household structure and where the labour market and welfare system intersect.

\section{Lone Parenthood in the Flanders}

Belgium's history is characterized by remarkable regional developments, as it consists of a Catholic northern part (Flanders) and an atheist southern part (Wallonia and Brussels) with different spheres of influence. While Flanders belonged to the German part of Europe, Wallonia resided in the Latin part. After the independence of the country, the linguistic borders always remained a cultural demarcation line in unitary Belgium, resulting in important disparities with regard to secularization and demographic behaviour. The enlightened ideas stemming from the French Revolution were more widely spread in the southern part of the country than in 
Roman Catholic Flanders. After World War II, the Belgian state structure evolved from a unitary state to a federal state, with central federal authority weakened and oversight of employment, education, and welfare transferred to two different types of regional authorities: communities and regions. Three communities - Flemish-, French-, and German-speaking - have jurisdiction over cultural matters, education, the use of languages, and matters relating to the individual, such as health policy (curative and preventive medicine) and social assistance (protection of youth, social welfare, aid to families, immigrant assistance services, and so forth). There are also three regions, which are geographically different from the communities: the Flemish region, the Brussels Capital region, and the Walloon region. These execute responsibilities with territorial impact, and their power extends to economic matters, employment, agriculture, water policy, housing, and public works.

With respect to Esping-Andersen's welfare state typology, Belgium is usually assigned to the group of Continental European welfare regimes (Esping-Andersen 1990). It has a low score in the cluster of liberal regimes and an average score in the cluster of social democratic regimes. In addition to having a high degree of decommodification, Belgium scores considerably high on "corporatism" and "etatism" indices. The system makes a strict division between regulations for employees, civil servants, and self-employed persons. A second trait is the degree to which health and unemployment benefits and (partially) pensions are related to earnings. This is a carry-over from the classic male breadwinner model, which is deeply rooted in the system. This principle is also represented in generous family benefits and social transfers, which support a traditional division of labour. Nevertheless, an elaborate childcare infrastructure, which enables women to combine work and family, provides evidence that Belgium also has characteristics of the dual-earner model.

Even though this chapter focuses only on the labour market transitions of Flemish lone mothers, we need to take into consideration the dual nature of the Belgian state structure. Divorce legislation as well as a large part of the labour market policy are centrally regulated, while economic prosperity and labour market participation clearly differ by region. The Flemish case is interesting because the relatively low female labour market participation is combined with a widespread use of "time leave" schemes. In Belgium, employees are entitled to interrupt their careers temporarily by means of the Career Break Scheme. During this period, employees are given a limited replacement income. The Flemish government encourages the use of the system by giving additional financial incentives. The majority (65\%) of people in the career break system in Belgium are situated in Flanders. Several options are available to take a career break: full-time breaks, part-time breaks, and specific thematic leave. This schedule was meant to encourage longer stays on the labour market and would encourage returns to work after maternity leave. The system does not compensate the whole income from labour. As a consequence, lone parents are scarcely using the system to enhance their work-life balance.

Next to the lower participation in leave schemes, we also find considerable lower labour participation levels among lone parents. According to the Labour Force Survey, approximately $68 \%$ of all lone parents are working, although not full time. One third of lone parents (35\%) work part time. We also observe higher percentages 
of lone parents in unemployment. Estimations of the Crossroads Bank of Social Security (CBSS Datawarehouse) show that the level of unemployment is five times higher among lone parents (32.2\%) than among dual earner families with children (6.5\%). Compared to the study of Geurts (2006), this is an increase of $14 \%$. Again, it comes as little surprise that unemployment among lone mothers is much higher than among lone fathers. The demographic evolution of Flemish lone parents and its relationship with poverty risk and changes in income is extensively presented in Chap. 10 in this Volume. However, it is worth highlighting here that in Flanders, lone parent families show a higher risk of poverty compared to any other family type and to the general population (Defever et al. 2013).

Given the characteristics of the welfare system and the schemes connected to labour market participation, the Flemish case represents an interesting field in which to observe the evolution of employment trajectories after lone parenthood. In fact, typical patterns of labour/welfare supply might appear differently within the group of lone mothers and therefore strengthen old inequalities or rather generate new disadvantages.

\section{Data and Methods}

Register data represent an invaluable source for studying social processes because they are not affected by memory bias. The Crossroads Bank of Social Security Datawarehouse (CBSS Datawarehouse, released 2009) combines demographic data from the National Register with labor market and income data from several Social Security offices in Belgium.

We selected a subsample of women between 25 and 55 years old who separated or got divorced in 2004 after cohabiting or being married. The age of 25 was chosen for reasons of data availability. The number of broken marriages and cohabitations (with children) for ex-partners below age 25 was too limited to be included in the analysis. The age of 55 concerns labour market attachment, which weakens rapidly after 55, showing a different sociological reality that is not the focus of this chapter. We additionally restrict our sample to those who do not live together with a partner and who live with one or more (own or step) children younger than 18 or younger than 25 if they do not have a labour market income (Letablier and Wall 2017). We ended up with a sample of 2602 lone mothers ${ }^{3}$, representing $34 \%$ of the original CBSS Datawarehouse sample of women aged 25- 55 in 2004.

For the first analytical step, we refer to the theoretical and methodological framework of sequence analysis, which considers individual processes unfolding over time - understood as a whole - as the primary unit of analysis. This approach to time-related phenomena is not grounded on any assumption about the generative process underlying the regularities in the sequence. In other words, causal modelling

${ }^{3}$ For a more detailed description of the sample identification procedure, please refer to Chap. 10 in this Volume. 
Table 12.1 States for the coding of the individual sequences representing employment trajectories

\begin{tabular}{l}
\hline State \\
\hline Full-time employment \\
\hline Part-time employment \\
\hline Unemployment/inactivity with benefits \\
\hline Minimum wage \\
$\begin{array}{l}\text { Unemployment/inactivity without } \\
\text { benefits }\end{array}$ \\
\hline
\end{tabular}

only intervenes in a second step of the analysis because the first aim is to describe sequence structures and the relationships among them to try to discover typologies. One of the main advantages of considering sequences as a unit of analysis is that it fosters the description of social processes that empirically result in patterns of events (Abbott 2001, 2004). Only after the identification of the latter is it possible to consider the determinants of such patterns and their configuration, as well as whether and how they can shape other processes.

Thus we built individual sequences starting in $2003^{4}$ (i.e. one year before the transition to lone motherhood occurred) and ending 5 years after the lone parenthood occurred. The original data were quarterly, so we ended up with a sequence of 24 quarters. Each time point was coded according to the position occupied by the individuals in or out of the labour market and the welfare system. In fact, in case of inactivity/unemployment, we define the individual position according to the welfare provision received. Table 12.1 displays the states used for coding the individual sequences.

Unemployment/inactivity benefits are available for those who are currently out of work, available to participate in the labour market, and living in Belgium. The minimum wage is a welfare provision individuals receive when they do not have sufficient means to live. Even though there is no incompatibility with labour income, as soon as people get a job, they earn too much to be entitled to the minimum wage. It follows that employed individuals usually do not receive a minimal wage and that even people with unemployment benefits are not entitled to this allowance. Important to notice is that childcare benefits and alimony from the ex-partner are not taken into account when determining entitlement to the minimum wage. The allowance is also increased when the beneficiary has minor (dependent) children.

Individual employment trajectories were then clustered in order to detect typical patterns of labour market participation after lone motherhood. In sequence analysis, the relationship between sequences is understood as the distance between them. It follows that prior to the clustering procedure on sequence objects, the computation of a pairwise dissimilarity matrix is needed. We used a variant of the classical

\footnotetext{
${ }^{4}$ All the analyses on sequences were performed using the software $\mathrm{R}$ version 3.1.2 (R Development Core Team 2014). The sequence analysis was conducted by using the $\mathrm{R}$ packages TraMine $\mathrm{R}$ (Gabadinho et al. 2011) and WeightedCluster (Studer 2013).
} 
Optimal Matching called Hamming distance (HAM) to compute the matrix due to its higher sensitivity to small time changes (Studer and Ritschard 2014)

Individual sequences were then clustered in order to maximize within-group homogeneity and between-groups heterogeneity: to this purpose, we used the partitioning around medoids method. Medoids are representative sequences having the smallest dissimilarity to the other sequences of the cluster they belong to ${ }^{6}$. According to the average silhouette width criterion used for detecting the number of clusters fulfilling these requisites (Kaufman and Rousseeuw 2005), an eight-cluster solution was detected as the optimal one ${ }^{7}$.

In the following analytical step, we estimated the differential probability of following those emerging patterns according to the variables of interest. We ran a multinomial logistic model in which the dependent variable was cluster membership. The independent variables refer to both individual and household characteristics: age of the mother 1 year before the transition to lone motherhood occurred (25-30, 31-35, 36-40, or 41 or more); civil status before lone motherhood (cohabiting or married); presence of children younger than 2 years old in the household (yes or no); and number of children younger than 17 years old in the household (none, 1, 2 , or 3 or more). The last two variables were measured 1 year before the transition to lone motherhood occurred. At present, the Belgian register data do not include information on the level of education. Table 12.2 shows the distribution of the independent variables considered in the analyses. Results from the multinomial regressions will be presented as average marginal effects (Wooldridge 2002), meaning that we will consider whether differentials exist in the probability of being assigned to each of the clusters according to pairwise comparisons between the categories of the independent variables and, if so, whether they are significant (Long 1997) ${ }^{8}$.

Finally, we connected previous results with additional empirical evidence concerning household income and partnership trajectories after lone parenthood. In the first case, we built individual sequences starting 1 year before and interrupted after 5 years that account for the position in the income quintile distribution at each point in time. For the partnership trajectories concerned, we consider the survival probability function of exiting lone motherhood by entering a new partnership. These additional descriptive results helped us to shed light on possible interaction between family/employment domains and the risk of economic vulnerability.

\footnotetext{
${ }^{5} \mathrm{~A}$ number of distance measures were tested and the structure of the clusters was substantially the same (results from the sensitivity tests are available upon request). We then selected the HAM option in order to maximize the timing sensitivity according to our substantive interest. HAM distance has all substitution costs equal to one and no indels.

${ }^{6}$ The corresponding algorithm pursues a global optimization: in contrast, hierarchical methods usually follow a local optimization that instead could not be optimal on a global level (for details, see Gabadinho et al. 2011).

${ }^{7}$ The average silhouette width (ASW) (Kaufman and Rousseeuw 2005) measures the coherence of the assignment of each sequence to a cluster and its value is allowed to vary from -1 to +1 . In our case, the ASW value for the 8-clusters solution using the HAM distance was 0.51.

${ }^{8}$ Marginal effects estimations were performed by using the SPost13 Stata commands (Long and Freese 2014).
} 
Table 12.2 Distribution of the independent variables

\begin{tabular}{|c|c|}
\hline & $\%$ \\
\hline \multicolumn{2}{|c|}{ Age of the mother (1 year before LM) } \\
\hline $25-30$ & 16.6 \\
\hline $31-35$ & 25.6 \\
\hline $36-40$ & 31.2 \\
\hline $41+$ & 26.6 \\
\hline \multicolumn{2}{|c|}{ Before lone motherhood } \\
\hline Cohabitation & 31.8 \\
\hline Marriage & 68.2 \\
\hline \multicolumn{2}{|c|}{$\begin{array}{l}\text { Children younger than } 2 \text { in the household } \\
\text { (1 year before LM) }\end{array}$} \\
\hline No & 87.4 \\
\hline Yes & 12.6 \\
\hline \multicolumn{2}{|c|}{$\begin{array}{l}\text { Children younger than } 17 \text { in the household } \\
\text { (1 year before LM) }\end{array}$} \\
\hline 0 & 5.2 \\
\hline 1 & 43.0 \\
\hline 2 & 38.0 \\
\hline $3+$ & 13.9 \\
\hline N. & 2602 \\
\hline
\end{tabular}

\section{Results}

In order to address our first research question concerning the variability of employment trajectories during and after lone motherhood, we started by running a cluster analysis on individual employment trajectories. The eight-cluster solution is displayed in Fig. 12.1. A general characteristic emerges from the very first sight: three clusters - namely "1. Reducers", "3. Increasers", and "5. Returners" - show a progressive shift from one prevalent state to another, while the remaining five clusters are characterized by a steady permanence in a single state. In other words, the first macro-group gathers the "movers" and the second one the "stayers". However, when we look at the "stayers" clusters, the importance of taking into account the year before lone parenthood (represented by the time point preceding the 0 value on the $\mathrm{x}$-axis that represents the year of the transition to lone motherhood) emerges clearly. In fact, we see that also for the "stayers" the actual dynamic of employment trajectories implies a change from before to after lone parenthood, signalled by the fact that the prevalence of a certain arrangement (for example, full-time work for cluster "2.Full-timers") changes in correspondence to the transition to lone motherhood becoming even stronger. 

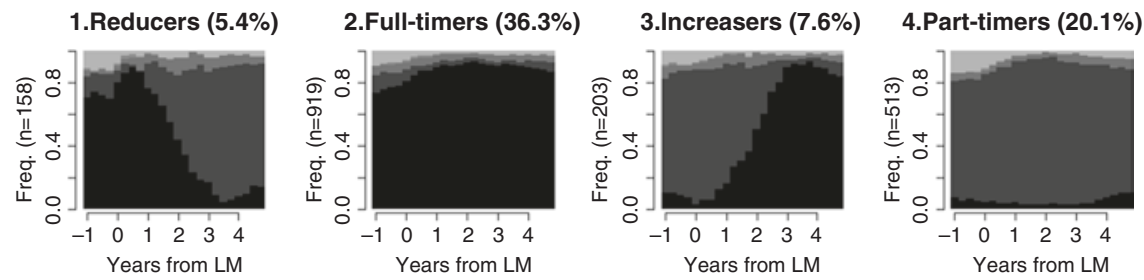

5.Returners $(4.1 \%)$

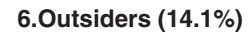

7.Subsidized (1.9\%)

8.Marginalized (10.5\%)
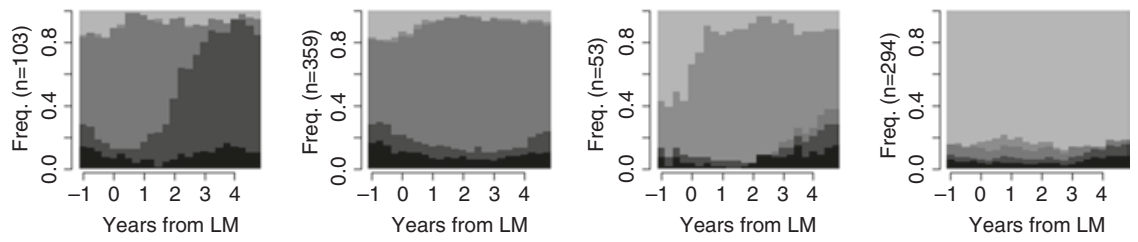

Full-time employment Part-time employment

ㅂ. Unemployment/inactivity with benefits Minimum wage

Fig. 12.1 States' distribution plots for the 8-cluster solution accounting for 1 year before and 5 after the transition to lone motherhood (LM). Data source: CBSS Datawarehouse 2009. Authors' own calculations

Fig. 12.1 makes clear that there are different ways to move/stay within and outside of the labour market structure. In fact, among the movers, those who belong to cluster "1.Reducers" progressively reduce their working hours, moving from fulltime to part-time employment, while those who are assigned to clusters "3. Increasers" and "5.Returners" increase their attachment over time. It is interesting to notice that such shifts start right before the end of the second year after the transition to lone motherhood. This can be interpreted - in the case of "1.Reducers"- as the consequence of an increasing need of care within the household, which forces mothers to reduce their labour supply after a first attempt to conciliate the previous arrangement and the new family arrangement; or-for the "Increasers" and the "Returners" as a response to the increasing need of income.

All in all, those who permanently stay within the labour market ("2.Full-timers" and "3.Part-timers") represent more than 50\% of the sample, while lone mothers who are steadily excluded make up 15\%. In three cases - "6.Ousiders", "7. Subsidized", and "8.Marginalized" - the transition to lone motherhood seems not to alter the previous arrangement. In these cases, we might think that lone motherhood acted by weakening the probability of exiting a situation of unemployment/inactivity. This might have made those women even more dependent on external help and undermined their employability 9 .

To estimate the probability of lone mothers being engaged in the different patterns of labour market participation according to their own and household characteristics,

\footnotetext{
${ }^{9}$ Distribution of individuals' characteristics within each cluster and clusters profiles can be found in Tables 12.A1 and 12.A2 in the Appendix.
} 
we estimated a multinomial logistic regression with cluster membership as the dependent variable. The results are presented in the four plots in Fig. 12.2 ${ }^{10}$ :

Plot (a) in Fig. 12.2 shows the probability of being assigned to each cluster according to age of the mother 1 year before the transition to lone parenthood. As mentioned above, our interest on this individual characteristic is two-fold. Firstly, young lone mothers might have experienced only short periods of paid work before the transition to lone parenthood and thus have less bargaining power to direct their strategy when the need arises to rearrange the labour supply. Secondly, both early motherhood and lone motherhood might have prevented them from catching up on their education, and low education represents a disadvantage in the labour market in terms of income and employment security. Two patterns emerge clearly from plot (a). Firstly, being a young lone mother (25-30) is associated with a significantly higher probability of being " 5 .Returners" or a "6.Outsiders" and to a lower probability of being "2.Full-timers" and "4.Part-timers" but also "8.Marginalized" compared to older lone mothers. The "8.Marginalized" pathway is an extremely disadvantaged one, which is more frequently followed also by women who experience lone motherhood when they are older than 41 . The latter are less likely to be "2.Full-timers", but at the same time more likely to increase their labour supply over the years (cluster "3.Increasers") compared to younger women.

Cohabiting instead of having been married before lone motherhood (plot (b) in Fig. 12.2) is associated to a higher probability of being "5.Returners" or "6. Outsiders", as the probability of cohabiting itself is higher for younger women and they are more likely to belong to those clusters. In contrast, the other clusters are less frequently associated with cohabitation than marriage prior to lone parenthood. These results seem to be unexpected if we consider that cohabitation is usually associated with a higher employment rate for women compared to marriage, while the two clusters in which ex-cohabiter lone mothers prevail show a relatively weak labour market attachment, if any. However, this might be due - once again - to the relatively younger age of lone mothers in these clusters, whose age and early motherhood might have prevented them from starting their own employment career.

When we move to consider the characteristics of the household, we basically account for variations in the care-giving investment mothers might face when the household structure changes. Plot (c) in Fig. 12.2 shows the average marginal effects of the presence of children younger than 17 in the household. Two main trends emerge. When compared to having only children older than 17 in the household, the presence of one or more younger children is associated with a higher probability of being "4.Part-timers" and a progressively lower likelihood of being "2.Full-timers" as the number of children increases. Moreover, the probability of being "6. Outsiders", "7.Subsidized", and "8.Marginalized" is higher for women caring for a higher number of children.

\footnotetext{
${ }^{10}$ Tables reporting the full results of the multinomial logistic regression model are available upon request.
} 

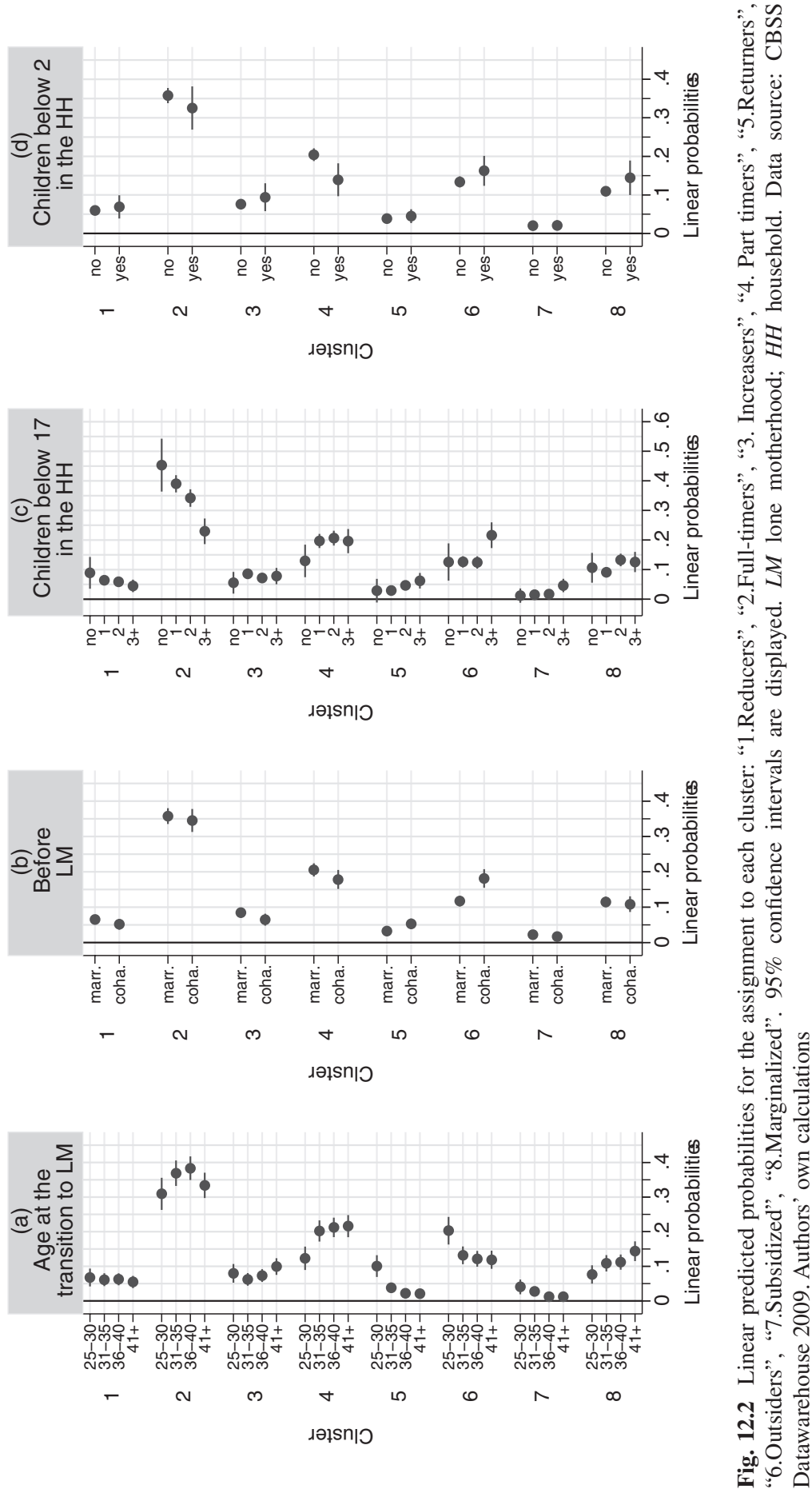
In addition, we tested for the association between employment patterns and the presence of a baby aged 0-2 in the household, which is likely to strongly increase the need for care. Estimates displayed in plot (d) in Fig. 12.2 show that the presence of an infant is significantly negatively associated only with a higher probability of being "4.Part-timers". In other words, it appears that the number of children to take care of rather than the very young age of one of them either represents a stronger barrier to certain pathways or prevents certain changes and thus traps mothers in certain disadvantaged positions.

Our last analytical step aims to highlight the connection between the employment pathways after lone motherhood and household income and partnership trajectories. Fig. 12.3 shows the income trajectories experienced by women belonging to the 8 clusters. The over-plotted black lines represent the survival probability to enter new partnerships for those same women. Considering the quintile income distribution starting from 1 year before the transition to lone motherhood allows us to establish evidence that this event triggers a worsening during the first year after its occurrence. The only exception is represented by cluster "7.Subsidized", since the proportion of women in the second quintile increases against a decrease in the third and in the first. In general, not many changes affect the experience of the "stayers" income-wise, but of course this occurs to a different extent depending on the fact of being in or out of the labour market. Marginalized lone mothers (cluster 8) are those most penalized, as they have neither unemployment benefits nor a minimal wage. Their household income remains steadily in the bottom quintile, even though half of
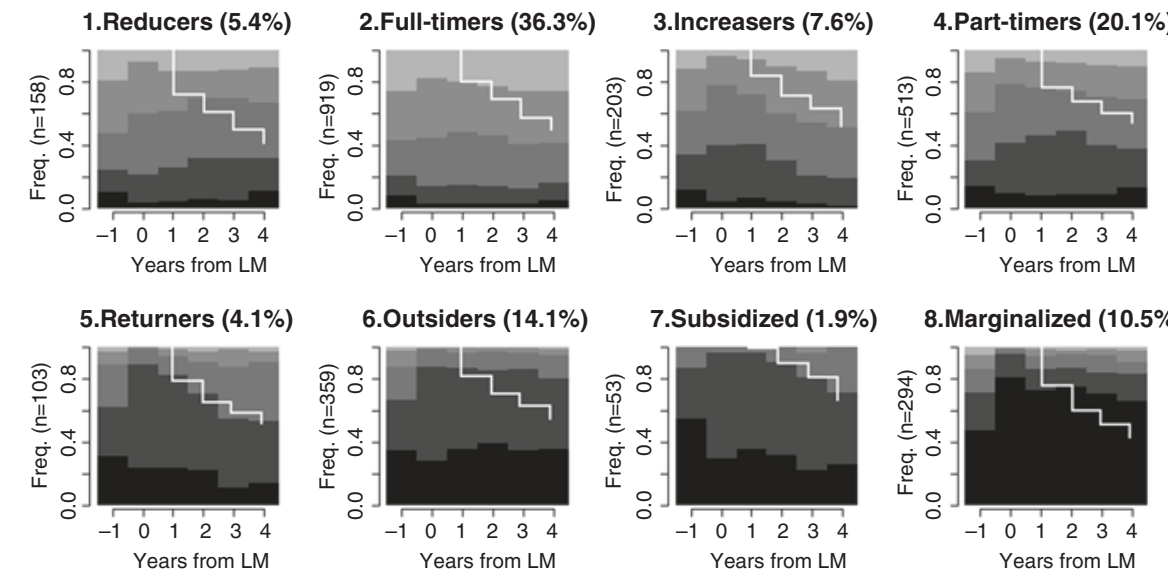

8.Marginalized (10.5\%)
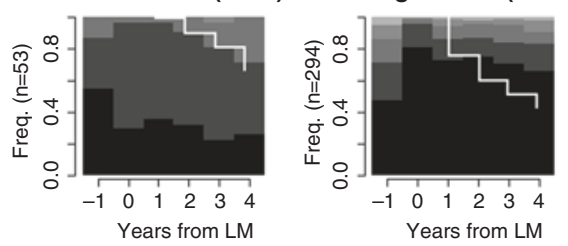

- 1st quantile $\square$ 3rd quantile $\square$ th quantile

2nd quantile 4 th quantile

Fig. 12.3 Distribution across the income quintiles for the 8-cluster solution from 1 year before to 5 years after the transition to lone motherhood. Survival curves for exiting from lone parenthood and re-partnering by starting a new cohabitation are over-plotted in white. $L M$ lone motherhood. Data source: CBSS Datawarehouse 2009. Authors' own calculations 
them re-partner within 3 years from the transition to lone motherhood - which is a higher rate compared to the other groups of stayers, among whom only 35-40\% of the women re-partner within the same time span.

Not surprisingly, a bigger number of income trajectories of full-timers than of part-timers are characterized by episodes in the top quintiles. However, when we compare these two groups to those who ended up with the same labour market arrangement (full time and part time, respectively) but started differently, we see that moving from part time to full time ("3.Increasers") led to a final income distribution characterized by a narrow top and a wider third quintile compared to that of "2.Full-timers". The same applies to the comparison between the "5.Returners" and the "4. Part-timers": the former move from unemployment/inactivity to part-time work, and they are massively distributed in the second and third quintiles. In contrast, almost $25 \%$ of the "4.Part-timers" are distributed in the top two quintiles.

This evidence further stresses the importance of seniority within the labour market in defining income profiles that then interact with needs, opportunities, and constraints lone mothers might encounter. Interestingly enough, the "1.Reducers" and the "5.Returners" are those who - on average - were more likely to re-partnered within the first 4 years after lone parenthood (55\%). In the first case, the income might be more favourably distributed on the top quintiles (despite having switched from full-time to part-time employment) because of re-partnering. In fact, we might expect a general decrease in the household income due to the reduction in the labour supply, but this seems to be buffered by an additional income from the new partner. In contrast, the change in the income distribution for the "5.Returners" is more likely to be a pure "employment effect" since re-partnering time for this subgroup is more delayed.

\section{Concluding Remarks}

In this chapter we provided descriptive evidence from the Flemish case on the variability of labour market participation patterns after women experience lone motherhood. A single-country study allowed us a better understanding of processes that are strongly shaped by institutional configurations and individual outcomes over the life course (Mayer 2005). Exploiting longitudinal data from the CBSS Datawarehouse, we could follow individual trajectories in the labour market or as welfare recipients during 4 years after this family transition occurred. Our exploratory analysis aimed to account for the complexity of within-group differences by identifying typical trajectories and estimating the relative probability of experiencing them according to individual and household characteristics. We chose to focus on within-lone-mother-group differences to highlight life-course phases of high vulnerability and potential social exclusion defined by the intersection of employment and welfare for individuals who experience this family transition. 
Our main results support a complex understanding of lone mothers' experience of paid work and welfare (Zagel 2013). In fact, the typology we obtain from clustering individual sequences reveals that there are many strategies lone mothers adopt when they have to cope with a new family composition. The variety of employment (and welfare) behaviours over the life course during the specific temporal window of "post-lone-parenthood" is consistent with previous findings adopting similar analytical strategies (Haux 2013; Zagel 2013; Stewart 2009). Furthermore, according to previous findings (Eamon and $\mathrm{Wu} 2011$ ), more than 50\% of the lone mothers in our sample have a strong labour market attachment, being and remaining in full- or part-time work for the whole time span considered. Another $12 \%$ either return after unemployment or increase the labour supply within the first 2 years after the transition to lone parenthood has occurred. In other words, the debate on the economic cost of lone parents actually concerns only a part of those who experience lone parenthood at some point during their life course. In our case, $15 \%$ of the lone mothers in the sample experienced long-lasting exclusion from the labour market, as they were either unemployed/inactive (cluster "6.Outsiders") or receiving the minimum wage (cluster "7.Subsidized"). However, a not negligible $10 \%$ does not receive welfare support in the absence of employment for all 4 years considered (cluster " 8 . Marginalized"). The persistence in such configurations reveals the presence of disadvantages in place even before lone parenthood, which we unfortunately cannot account for due to the lack of information - for example - on education or migration status in register data.

Nevertheless, we found the individual and household characteristics we considered as possible "barriers" to employment are differently associated to the patterns we identified. In this case, the within-group variety appears to be crucial in defining more vulnerable profiles: young lone mothers seem less able to engage in paid work and thus experience relatively long periods as recipients of welfare measures, while having had the time to build their careers before lone motherhood seems to keep older lone mothers remain strongly attached to employment. In other words, the age at which they have children and/or experience lone motherhood is crucial in understanding their future exclusion from the labour market. In the new social risks framework (Bonoli 2005; Vandecasteele 2011), policies should address exactly such situations in which long-term disadvantages that emerge when the timing of life transitions in certain domains matches with traditional factors of inequalities such as lower education.

Finally, in the Flemish case it is the number of children below 17 in the household rather than the presence of very small children that defines different probabilities of pursuing a certain labour market strategy. Specifically, the bigger the family size, the higher the probability of having a strong labour market attachment through full-time jobs, and the lower the likelihood of being unemployed/inactive and receiving welfare benefits. 
Besides the strength represented by the use of longitudinal register data on labour market participation and by the possibility to make a fine-grained distinction between types of welfare support and employment arrangements, some limitations of this work have to be considered. First, a specific group of lone mothers falls out of our scope because the initial sample of our study comprised only women who either were married or were cohabiting before lone parenthood. Women who live at their parents' house or are lone mothers by choice remain out of sight in this analysis. It follows that we might underestimate the incidence of trajectories characterized by unemployment and welfare dependency because the frailest women (lone mothers at first birth and very young lone mothers) are not in our sample. We believe this bias is limited in this case because Belgium scores very low $(0.6 \%)$ on fertility rate of women between 15 and 19 (World Bank 2015). The rate of teen pregnancies is also low and stable around 9\% (De Wilde 2008). As shown elsewhere in this book, many other issues also concern lone parenthood at this young age besides labour market strategies.

This data limitation applies to another crucial issue: the Belgian register data currently do not report individuals' educational level. When analysing employment trajectories, education represents a potential confounder when estimating the probability of being more or less attached to the labour market, and this is particularly true for women (DiPrete and Buchmann 2013).

Further research should face these limitations, but we believe that our contribution adds to the recent body of evidence on lone mothers' strategies on the labour market. Together with Berrington (2014), Haux (2013), Whitworth (2013), and Zagel (2013), our single-country case study again shows the complexity and diversity of lone parenthood, more specifically among lone mothers. Survey data often limit researchers' ability to dip deep into this complexity, while registers are currently limited to a single-country approach. Future collaborative studies may focus on combining the power of registers in a comparative endeavour that aims to combine labour market strategies and income positions cross nationally and disentangle the subtle influences of welfare states on these strategies. This is important since we have shown in this chapter that a majority of lone mothers are active on the labour market. It is the small group of frail lone mothers that warrants our attention because they are most likely to struggle with poverty and perpetuate their disadvantaged position in their future life courses.

Acknowledgements This publication benefited from the support of the Swiss National Centre of Competence in Research LIVES - Overcoming vulnerability: life course perspectives, which is financed by the Swiss National Science Foundation. Emanuela Struffolino is grateful to the Swiss National Science Foundation for the financial support. The authors also thank the Belgian Crossroads Bank of Social Security and more particular Chis Brijs for their cooperation in this research.

This paper benefited from the support of the Swiss National Centre of Competence in Research LIVES - Overcoming Vulnerability: Life Course Perspectives, which is financed by the Swiss National Science Foundation (Grant number: 51NF40-160590). 


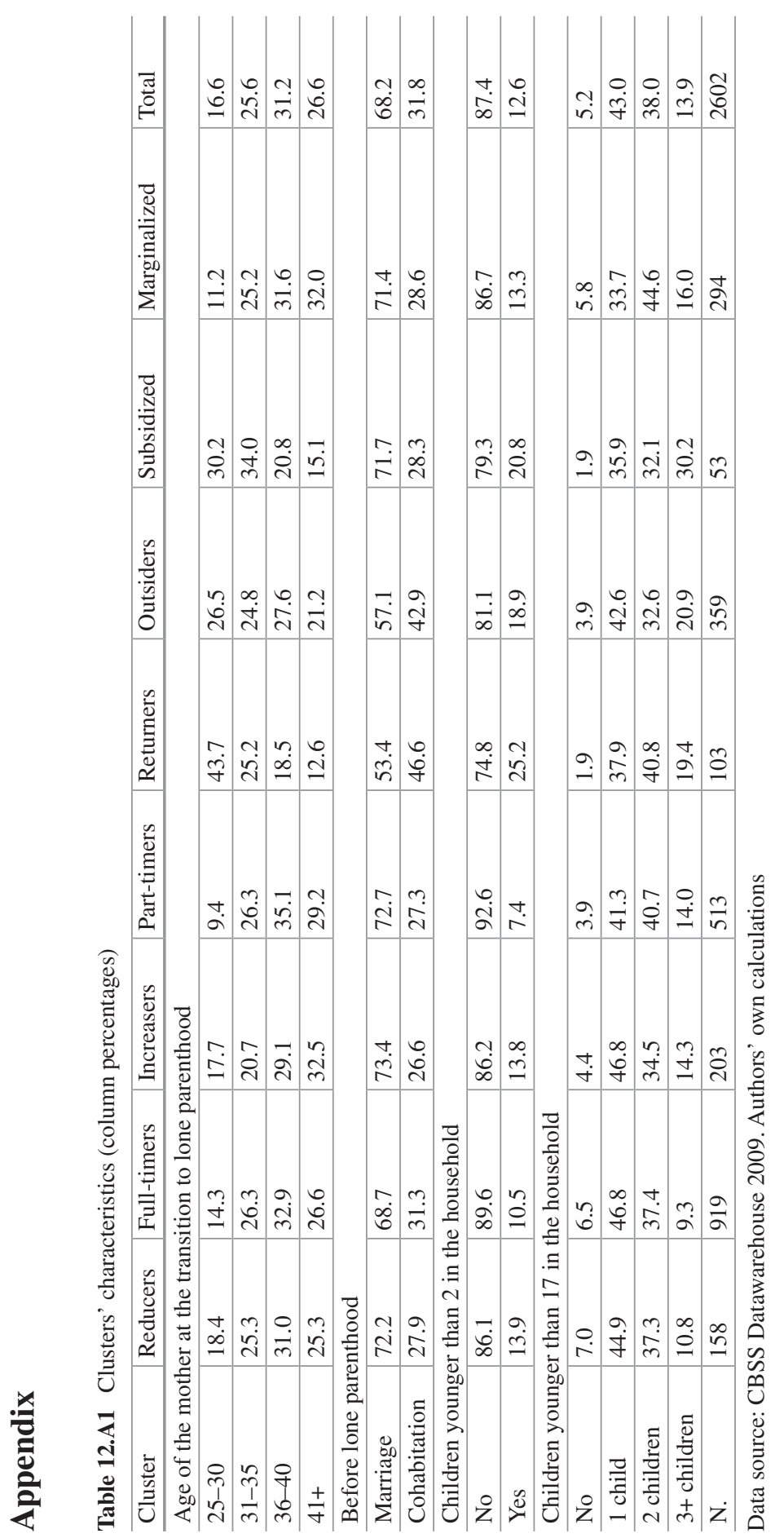




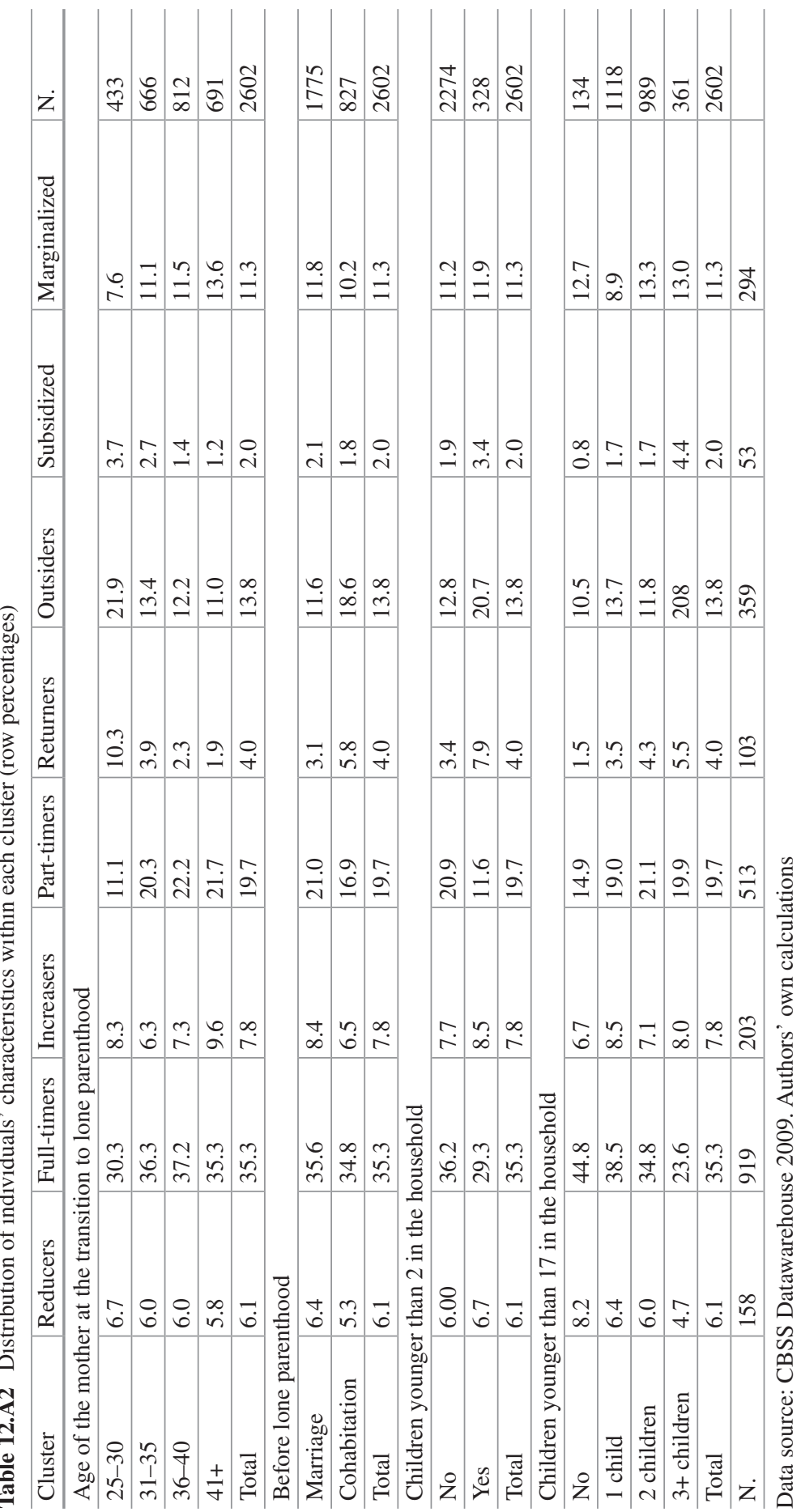




\section{References}

Abbott, A. (2001). Time matters. On theory and method. Chicago: University of Chicago Press.

Abbott, A. D. (2004). Methods of discovery: Heuristics for the social sciences. New York: WW Norton \& Company.

Ahn, H. (2012). Child care subsidy, child care costs, and employment of low-income single mothers. Children and Youth Services Review, 34(2), 379-387. http://doi.org/10.1016/j. childyouth.2011.11.010

Andreß, H. J., \& Lohmann, H. (2008). The working poor in Europe: Employment, poverty and globalisation. Cheltenham/Northampton: Edward Elgar Publishing.

Andreß, H.-J., Borgloh, B., Bröckel, M., Giesselmann, M., \& Hummelsheim, D. (2006). The economic consequences of partnership dissolution-A comparative analysis of panel studies from Belgium, Germany, Great Britain, Italy, and Sweden. European Sociological Review, 22(5), 533-560.

Athreya, K., Reilly, D., \& Simpson, N. B. (2010). Earned income tax credit recipients: Income, marginal tax rates, wealth, and credit constraints. FRB Richmond Economic Quarterly, 96(3), 229-272.

Bauman, K. J. (2002). Welfare, work and material hardship in single parent and other households. Journal of Poverty, 6(1), 21-40.

Becker, G. S. (1975). Human capital: A theoretical and empirical analysis, with special reference to education. New York: National Bureau of Economic Research.

Berrington, A. (2014). The changing demography of lone parenthood in the UK (ESRC Center for Population Change, Working paper 48).

Boeckmann, I., Misra, J., \& Budig, M. J. (2014). Cultural and institutional factors shaping mothers' employment and working hours in postindustrial countries. Social Forces, 93, 1-33.

Bonoli, G. (2005). The politics of the new social policies: Providing coverage against new social risks in mature welfare states. Policy \& Politics, 33(3), 431-449.

Cancian, M., \& Meyer, D. R. (2000). Work after welfare: Women's work effort, occupation, and economic well-being. Social Work Research, 24(2), 69-86.

Chevalier, A., \& Viitanen, T. K. (2003). The long-run labour market consequences of teenage motherhood in Britain. Journal of Population Economics, 16(2), 323-343.

Christopher, K., England, P., McLanahan, S., Ross, K., \& Smeeding, T. (2000). Gender inequality in poverty in affluent nations: The role of single motherhood and the state (Center for Research on Child Wellbeing Working Paper \#00-12).

Cohen, P. N. (2002). Extended households at work: Living arrangements and inequality in single mothers' employment. Sociological Forum, 17(3), 445-463. https://doi.org/10.102 3/A:1019631107686.

Connelly, R., \& Kimmel, J. (2003). The effect of child care costs on the employment and welfare recipiency of single mothers. Southern Economic Journal, 69, 498-519.

Cooke, G., \& Lawton, K. (2008). Working out of poverty. Geneva: Institute for Public Policy Research.

Daly, M. (2000). A fine balance: Women's labor market participation in international comparison. In F. Scharpf \& V. Schmidt (Eds.), Welfare and work in the open economy Volume II: Diverse responses to common challenges in twelve countries. New York: Oxford University Press.

Daly, M. (2011). What adult worker model? A critical look at recent social policy reform in Europe from a gender and family perspective. Social Politics, 18(1), 1-23.

Daycare Trust. (2011). Childcare costs in 2011. London: Daycare Trust.

Defever, C., Van Lancker, W., Mortelmans, D., \& Cantillon, B. (2013). De inkomenspositie van alleenstaande ouders. In M. Callens (Ed.), De inkomenspositie van alleenstaande ouders. Brussel: Studiedienst van de Vlaamse Gemeenschap.

De Regt, S., Mortelmans, D., \& Marynissen, T. (2013). Financial consequences of relationship dissolution: A longitudinal comparison of formerly married and unmarried cohabiting men and women. Sociology, 47(1), 90-108. 
De Vaus, D., Gray, M., Qu, L., \& Stanton, D. (2014). The economic consequences of divorce in Australia. International Journal of Law, Policy and the Family, 28(1), 26-47. https://doi. org/10.1093/lawfam/ebt014.

De Wilde, M. (2008). Tienerzwangerschappen in België in cijfers van 1996 tot 2005. Tijdschrift Voor Sociologie, 29(1), 89-103.

DiPrete, T. A., \& Buchmann, C. (2013). The rise of women. New York: SAGE.

DiPrete, T. A., \& McManus, P. A. (2000). Family change, employment transitions, and the welfare state: Household income dynamics in the United States and Germany. American Sociological Review, 65, 343-370.

Doiron, D. J. (2004). Welfare reform and the labour supply of lone parents in Australia: A natural experiment approach. Economic Record, 80(249), 157-176.

Dowler, E. (1998). Budgeting for food on a low income in the UK: The case of lone-parent families. Food Policy, 22(5), 405-417.

Drobnič, S. (2000). The effects of children on married and lone mothers' employment in the United States and (West) Germany. European Sociological Review, 16(2), 137-157.

D’Souza, J., Conolly, A., \& Purdon, S. (2008). Analysis of the choices and constraints questions on the families and children study (Vol. 481). Norwich: Department for Work and Pensions.

Duncan, S., \& Edwards, R. (1997). Lone mothers and paid work - Rational economic man or gendered moral rationalities? Feminist Economics, 3(2), 29-61. http://doi.org/10.1080/135457097338690

Eamon, M. K., \& Wu, C.-F. (2011). Effects of unemployment and underemployment on material hardship in single-mother families. Children and Youth Services Review, 33(2), 233-241.

Ermisch, J. F., \& Wright, E. (1995). Lone parenthood and employment: Male-female differences in Great Britain. Labour Economics, 2(3), 299-317.

Esping-Andersen, G. (1990). The three worlds of welfare capitalism. Cambridge: Polity Press.

Esping-Andersen, G. (1999). Social foundations of postindustrial economies. Oxford: Oxford University Press.

Friedland, D. S., \& Price, R. H. (2003). Underemployment: Consequences for the health and wellbeing of workers. American Journal of Community Psychology, 32(1-2), 33-45.

Gabadinho, A., Ritschard, G., Müller, N. S., \& Studer, M. (2011). Analyzing and visualizing state sequences in R with TraMineR. Journal of Statistical Software, 40(4), 1-37.

Garfinkel, I., McLanahan, S., \& Robins, P. K. (1994). Child support and child well-being. Washington, DC: The Urban Insitute Press.

Geurts, K. (2006). De arbeidsmarktpositie van alleenstaande ouders. Nieuwe bevindingen uit het Datawarehouse Arbeidsmarkt en Sociale Bescherming. Steunpunt Werkgelegenheid, Arbeid en vorming. Eindrapport WAV, Leuven: KU Leuven. Retrieved from http://docplayer. nl/14585033-De-arbeidsmarktpositie-van-alleenstaande-oudersnieuwe-bevindingen-uit-hetdatawarehouse-arbeidsmarkt-en-sociale-bescherming.html

Gingerbread Report. (2012). The only way is up? The employment aspirations of single parents. Gingerbread.Retrieved from https://gingerbread.org.uk/content/667/Policy-work---employment

Harris, K. M. (1993). Work and welfare among single mothers in poverty. American Journal of Sociology, 99(2), 317-352.

Haux, T. (2013). Understanding employment barriers for lone parents in Great Britain: Research gaps and missed opportunities. Social Policy \& Administration, 47(4), 468-482. http://doi. org $/ 10.1111 /$ spol.12030

Herbst, C. M., \& Tekin, E. (2011). Do child care subsidies influence single mothers' decision to invest in human capital? Economics of Education Review, 30(5), 901-912. http://doi. org/10.1016/j.econedurev.2011.03.006

Immervol, H., \& Scarpetta, S. (2012). Activation and employment support policies in OECD countries. An overview of current approaches. IZA Journal of Labor Policy, 1(19), 1-20. https://doi. org/10.1186/2193-9004-1-9.

Jarvis, S., \& Jenkins, S. P. (1999). Marital splits and income changes: Evidence from the British household panel survey. Population Studies, 53(2), 237-254. http://doi. org/10.1080/00324720308077

Jenkins, S. (2009). Marital splits and income changes over the longer term. In M. Brynin \& J. Ermisch (Eds.), Changing relationships. London: Routledge. 
Kasparova, D., Marsh, A., Vegeris, S., \& Perry, J. (2003). Families and children 2001: Work and childcare (Vol. 191). Washington, DC: Department for Work and Pensions.

Kaufman, L., \& Rousseeuw, P. J. (2005). Finding groups in data: An introduction to cluster analysis. Hoboken: John Wiley \& Sons.

Kiernan, K. E. (2004). Cohabitation and divorce across nations and generations. In K. P. L. ChaseLansdale, E. Kiernan, \& R. J. Friedmann (Eds.), Human development across lives and generations: The potential for change (pp. 139-203). New York: Cambridge University Press.

Korpi, W. (2000). Faces of inequality: Gender, class, and patterns of inequalities in different types of welfare states. Social Politics: International Studies in Gender, State \& Society, 7(2), 127-191.

Korpi, W., Ferrarini, T., \& Englund, S. (2013). Women's opportunities under different family policy constellations: Gender, class, and inequality tradeoffs in western countries re-examined. Social Politics: International Studies in Gender, State \& Society, 20(1), 1-40.

Letablier, M.-T., \& Wall, K. (2017). Changing lone parenthood patterns: New challenges for policy and research. In L. Bernardi \& D. Mortelmans (Eds.), Lone parenthood in the life course. Cham: Springer.

Lewis, J. (2009). Work-family balance, gender and policy. Cheltenham/Northampton: Edward Elgar Publishing.

Long, J. S. (1997). Regression models for categorical and limited dependent variables (Vol. 7). Thousand Oaks: Sage Publications.

Long, J. S., \& Freese, J. (2014). Regression models for categorical dependent variables using Stata (3rd ed.). Texas: Stata Press.

Looze, J. (2014). Young women's job mobility: The influence of motherhood status and education. Journal of Marriage and Family, 76(4), 693-709. https://doi.org/10.1111/jomf.12122.

Mayer, K. U. (2005). Life courses and life chances in a comparative perspective. In S. Svallfors (Ed.), Analyzing inequality: Life chances and social mobility in comparative perspective (pp. 17-55). Stanford: Stanford University Press.

Mckay, S. (2002). The dynamics of lone parents, employment and poverty in Great Britain. Sociologia e politica sociale, 2, 1-26.

Millar, J., \& Ridge, T. (2008). Relationships of care: Working lone mothers, their children and employment sustainability. Journal of Social Policy, 38(01), 103. http://doi.org/10.1017/ S0047279408002572

Millar, J., \& Rowlingson, K. (2001). Lone parents, employment and social policy: Cross-national comparisons. Bristol: The Policy Press.

Mincer, J. A. (1974). Schooling, experience and earnings. New Yrok: Columbia University Press. Retrieved from http://www.nber.org/chapters/c1765.pdf.

Moffitt, R., Cherlin, A., Burton, L., King, M., \& Roff, J. (2002). The characteristics of families remaining on welfare. Baltimore: Johns Hopkins University.

Mortelmans, D. (2017). Income trajectories of lone parents after divorce. In L. Bernardi \& D. Mortelmans (Eds.), Lone parenthood in the life course. Cham: Springer.

OECD. (2014). OECD family database. Paris: OECD.

Ondrich, J., Spiess, C. K., Yang, Q., \& Wagner, G. G. (2003). The liberalization of maternity leave policy and the return to work after childbirth in Germany. Review of Economics of the Household, 1(1-2), 77-110.

Plantenga, J., Remery, C., Mairhuber, I., Meulders, D., Beleva, I., Ellina, C., et al. (2010). Flexible working time arrangements and gender equality: A comparative review of thirty European countries. Luxembourg: European Commission.

Poortman, A.-R. (2000). Sex differences in the economic consequences of separation a panel study of the Netherlands. European Sociological Review, 16(4), 367-383.

Rake, K. (2000). Women's incomes over the lifetime. London: The Stationery Office.

R Development Core Team. (2014). R: A language and environment for statistical computing. Vienna: R Foundation for Statistical Computing.

Ruggeri, K., \& Bird, C. E. (2014). Single parents and employment in Europe (RAND EUROPE). Europe: European Commission. 
Smock, P. J. (1994). Gender and the short-run economic consequences of marital disruption. Social Forces, 73(1), 243-262.

Smock, P. J., Manning, W. D., \& Gupta, S. (1999). The effect of marriage and divorce on women's economic well-being. American Sociological Review, 64, 794-812.

Snoeckx, L., Dehertogh, B., \& Mortelmans, D. (2008). The distribution of household tasks in first-marriage families and stepfamilies across Europe. In J. Pryor (Ed.), The international handbook of stepfamilies: Policy and practice in legal, research, and clinical environments (pp. 277-298). Hoboken: Wiley.

Stewart, K. (2009). Employment and wage trajectories for mothers entering low-skilled work: Evidence from the British lone parent cohort. Social Policy \& Administration, 43(5), 483-507. http://doi.org/10.1111/j.1467-9515.2009.00675.x

Studer, M. (2013). Weighted Cluster Library Manual: A practical guide to creating typologies of trajectories in the social sciences with $R$ (LIVES Working Papers, 24).

Studer, M., \& Ritschard, G. (2014). What matters in differences between life trajectories: A comparative review of sequence dissimilarity measures. Journal of the Royal Statistical Society, 179(2), 481-511. https://doi.org/10.1111/rssa.12125.

Taylor-Gooby, P. (2004). New risks and social change. In P. Taylor-Gooby (Ed.), New risks, new welfare: The transformation of the European Welfare State (pp. 1-28). New York: Oxford University Press. https://doi.org/10.1093/019926726X.001.0001.

Tomaszewski, W., Chanfreau, J., \& Barnes, M. (2010). Lone parents and employment: An exploration of findings from the families and children study 2006-08 (Vol. 93). London: Department of Work and Pensions. Retrieved from http://dera.ioe.ac.uk/1981/

Uunk, W. (2004). The economic consequences of divorce for women in the European Union: The impact of welfare state arrangements. European Journal of Population/Revue Europeenne de Demographie, 20(3), 251-285.

Vandecasteele, L. (2010). Poverty trajectories after risky life course events in different European welfare regimes. European Societies, 12(2), 257-278.

Vandecasteele, L. (2011). Life course risks or cumulative disadvantage? The structuring effect of social stratification determinants and life course events on poverty transitions in Europe. European Sociological Review, 27(2), 246-263.

Van der Lippe, T., \& Van Dijk, L. (2002). Comparative research on women's employment. Annual Review of Sociology, 28, 221-241.

Voges, W., Buhr, P., \& Zwick, M. (1996). Einmal drin-immer drin? Sozialhilfebezug von Familien. In J. Behrens \& W. Voges (Eds.), Kritische Übergänge. Statuspassagen Und Sozialpolitische Institutionalisierung (pp. 285-322). Frankfurt A. M./New York: Campus.

Wagener, M., Defever, C., \& Mortelmans, D. (2014). Les familles monoparentales en Belgique : une approche par les trajectoires professionnelles. In I. Pannecoecke, W. Lahaye, J. Vranken, \& R. Van Rossem (Eds.), Pauvreté en Belgique : annuaire 2014 (pp. 91-131). Gent: Academia Press.

Western, B., Bloome, D., \& Percheski, C. (2008). Inequality among American families with children, 1975 to 2005. American Sociological Review, 73(6), 903-920.

Whitworth, A. (2013). Lone parents and welfare-to-work in England: A spatial analysis of outcomes and drivers. Social Policy and Administration, 47(7), 826-845. https://doi. org/10.1111/j.1467-9515.2012.00868.x.

Wooldridge, J. M. (2002). Econometric analysis of cross section and panel data. Cambridge and London: MIT Press.

World Bank. (2015). World development indicators: Adolescent fertility rate. Retrieved March 3, 3015, from http://data.worldbank.org/indicator/SP.ADO.TFRT

Wu, C.-F., Cancian, M., \& Meyer, D. R. (2008). Standing still or moving up? Evidence from Wisconsin on the long-term employment and earnings of TANF participants. Social Work Research, 32(2), 89-103.

Zagel, H. (2013). Are all single mothers the same? Evidence from British and West German women's employment trajectories. European Sociological Review, 30(1), 49-63. http://doi. org/10.1093/esr/jct021 
Emanuela Struffolino is senior researcher at the "Demography and Inequality" research group at the WZB Berlin Social Science Center and at the chair of Microsociology at Humboldt University of Berlin. She obtained her PhD in Sociology at the University of Milano-Bicocca and worked as research fellow at the National Centre of Competence in Research LIVES - Overcoming Vulnerability: Life course perspectives (NCCR Lives), Lausanne, Switzerland. Her research interests include life-course sociology, gender inequalities in the labor market, social stratification, and methods for longitudinal data.

Dimitri Mortelmans is Full Professor of Sociology at the Faculty of Political and Social Sciences of the University of Antwerp, Belgium. He teaches qualitative research methods, applied multivariate statistics and advanced topics in family sociology, life-course sociology and demography. He is head of the Centre for Longitudinal and Life Course Studies (CLLS). His research concentrates on family sociology and sociology of labour. He has published on divorce, new constituted families, gendered labour careers and work-life balance. He is also the main author of the Step in Statistics book series of which six volumes have been published (in Dutch). On qualitative methodology, he published the Handbook of Qualitative Research Methods and Qualitative Analysis with Nvivo.

Open Access This chapter is licensed under the terms of the Creative Commons Attribution 4.0 International License (http://creativecommons.org/licenses/by/4.0/), which permits use, sharing, adaptation, distribution and reproduction in any medium or format, as long as you give appropriate credit to the original author(s) and the source, provide a link to the Creative Commons license and indicate if changes were made.

The images or other third party material in this chapter are included in the chapter's Creative Commons license, unless indicated otherwise in a credit line to the material. If material is not included in the chapter's Creative Commons license and your intended use is not permitted by statutory regulation or exceeds the permitted use, you will need to obtain permission directly from the copyright holder.

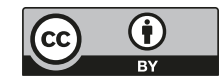

